\title{
Monitor of Water Quality Using The Grey Mullet (Mugil Cephalus) as Bioindicator in Two Egyptian Lakes
}

\author{
${ }^{1}$ Eman, G.E. Helal, ${ }^{2}$ Abd El-Atti, M. S., ${ }^{3}$ Shaymaa Hussein and ${ }^{4}$ Yasmina, M. Ekraim \\ ${ }^{1 \& 4}$ Zoology Department, Faculty of science (Girls), Al-Azhar University, Cairo, Egypt. \\ ${ }^{2}$ Zoology Department, Faculty of Science, Zagazig University, Egypt. \\ ${ }^{3}$ Department of Cytology and Histology, Fac. Vet. Med. Cairo University, Egypt.
}

Corresponding author: Eman Helal, email: emanhelal@ hotmail.com, Mobile:00201001025364, orcid.org/0000-0003-0527-7028

\begin{abstract}
Background-Burullus Lake has brackish water and agricultural, industrial and sewage drainage water represent the major inflows and it represents one of the most subjected lakes to serious pollutants at the delta's coastline. Mugil cephalus is one of the most important food fish species for the Egyptian people. This study was conducted to explain the effect of water pollution of both Qarun and Burullus Lakes on some biochemical and histological characteristics of mullet collected from both Lakes. Our results showed that water collected from Burullus Lake has higher levels of lead and cadmium than Qarun Lake. The liver function analysis showed that there were no significant differences between levels of GGT in M. cephalus livers collected from both Lakes. ALT and AST were significantly increased in livers of fishes collected from Qarun Lake than Burullus Lake, cholesterol, triglycerides, RF1, RF2, high density lipoproteins (HDL), low density lipoproteins (LDL) and very low density lipoproteins (VLDL) in muscles of the mullet collected from Burullus Lake were highly significant increase, while total proteins were significantly decreased in comparison with mullet of Qarun Lake. Histopathological investigations revealed that livers of mullet cached from both Lakes were suffered from marked area of hemorrhage, aggregates of hemosiderin granules and vacuolated hepatocytes. Ultrastructural observation showed degenerated and swelled cylindrical mitochondria in liver obtained from Burullus Lake with accumulation of lipid droplets and degenerated cytoplasmic organoids. Hepatocyte from Qarun Lake showed apoptotic nuclei, degenerated, swelled and cylindrical mitochondria, lipid droplets and dilated rough endoplasmic reticulum. Von Kupffer cells in liver of both lakes contained abundant lysosomes with corrugated walls and numerous cytoplasmic vacuoles. The kidney sections of mullet of both Lakes showed necrosis in the tubular epithelial lining with scattered apoptotic cells and interstitial inflammatory infiltrate.
\end{abstract}

Keywords: Bioindicator, Monitor, Mugil cephalus, Water quality, Histology, Transmission Electron Microscope, Hepatocytes, Kidney.

\section{INTRODUCTION}

Qarun Lake has an average area of about $226 \mathrm{~km} 2$; the lake is shallow, with average depth of $4 \mathrm{~m}$ and receives annually about 470 million cubic meters of drainage water (Agricultural and sewage) through 12 drains ${ }^{(\mathbf{1})}$. Burullus Lake is a brackish water Lake in the Nile Delta in Egypt and located in Kafr El-Sheikh Governorate. Burullus Lake is the second largest Lake along the Mediterranean Sea and represents one of the most subjected Lakes to pollution at the delta's coastline. This Lake serves as reservoirs for drainage waters contaminated with anthropogenic materials (2). Heavy metals are a serious hazard for aquatic ecosystems and human health and they negatively affect aquatic life functioning through accumulation resulting physiological/growth disturbances in aquatic life forms ${ }^{(3)}$. Heavy metals are commonly found in natural waters and may become highly toxic when present in high concentrations ${ }^{(4)}$. Aquatic organisms take up metals from water and their diet. A study suggested that dietary metal exposure is the predominant source for metal accumulation in some aquatic organisms ${ }^{(5)}$. High concentrations of heavy metals have potential genotoxic effects and genotoxicty is possibly related to agricultural and domestic activities ${ }^{(6)}$. A long-lasting exposure to lead and cadmium may cause changes in the immune response ${ }^{(7)}$. $\mathrm{Pb}$ targets the proximal tubules of the kidneys and is capable of inducing nephrotoxicity ${ }^{(8)}$. There has been a widespread world-wide use of flathead mullet, Mugil cephalus, in fish biomonitor studies within the coastal zone ${ }^{(9)}$. At present, the direct immunotoxicity of heavy metals is the subject of extensive studies. The grey mullet normally feed on algae in fresh water and can acclimate to different levels of salinity ${ }^{(\mathbf{1 0})}$. The genotoxic effects of metal pollution in Oreochromis niloticus and Mugil cephalus in Lake Qarun were studied and the results showed that high concentrations of heavy metals had a potential genotoxic effects and genotoxicty was related to agricultural and domestic activities ${ }^{(11)}$.This research was carried out to measure levels of $\mathrm{Cd}$ and $\mathrm{Pb}$ in the 
water of both Qarun and Burullus Lakes and investigated the effects of polluted water on some biochemical and histopathological characteristics of the grey mullet $M$. cephalus.

\section{Material and methods}

\section{Study areas}

The two investigated lakes were Qarun which is located about $80 \mathrm{~km}$ southwest of Cairo and Burullus lagoon which is located between the two Nile branches Rosetta to the west and Damietta to the east, Kafr ElSheikh Governorate, Egypt.

\section{Water Sampling}

Surface water samples were collected about $20 \mathrm{~cm}$ below the water surface to avoid floating matter. Stoppered, acid-washed, polyethylene bottles were used as sampling devices. Water samples were filtered in the field using a polypropylene syringe fitted with a $0.45 \mathrm{~mm}$ Millipore cellulose acetate filter and acidified for preservation.

\section{Fish Sampling}

A total of approximately number of fifty fish of Mugil cephalus were randomly caught from each lake. All fish used were of uniform size $(10-9.6 \mathrm{~cm}$ and weight 16.81- 14.94g). Fish were collected in closed meshed nets before being transferred in an ice box at $4^{\circ} \mathrm{C}$ until reach to the laboratory of Physiology, Zoology Department, Faculty of Science (Girls), Al-Azhar University. Thereafter, fishes were dissected to remove liver, kidney and muscle tissues.

\section{Tissue preparation}

A known weight of each organ (liver, kidney and muscles) was homogenized in saline solution by using the electric homogenizer, for $2 \mathrm{~min}$. The homogenated specimens were centrifuged at 4000 r.p.m. for $15 \mathrm{~min}$. at $2{ }^{\circ} \mathrm{C}$ in a refrigerator centrifuge. The supernatant solution was used or stored at $-20{ }^{\circ} \mathrm{C}$ until the latter examinations.

\section{Biochemical analysis}

Concentrations of total proteins, total lipids, triglycerides, total cholesterol in muscles ,HDL, LDL, VLDL, Creatinine, urea, aspartate aminotransferase (AST), alanine aminotransferase (ALT), GammaGlutamyl transferase (GGT), RF1 and RF2 activities were measured by using biom rieux SA (France) Kits .

\section{Light microscopy preparations}

The livers and kidneys of Mugil cephalus were dissected, fixed in $10 \%$ formalin and dehydrated through ascending series of ethanol. Tissues were embedded in paraffin wax and sections 4-6 $\mu \mathrm{m}$ thick were cut, stained with hematoxylin and eosin. ${ }^{(12}$

\section{Transmission electron microscopy:}

Small pieces of liver tissue were fixed in glutaraldehyde in phosphate buffer ${ }^{(13)}$. Specimens were post fixed in $1 \%$ osmium tetraoxide for one hours, washed in $0.1 \mathrm{M}$ phosphate buffer $(\mathrm{pH} 7.3)$, then dehydrated in graded ethanol and embedded in open araldite mixture ${ }^{(14)}$. Semi thin sections $(1 \mu \mathrm{m})$ were cut, stained with toluidine blue ${ }^{(15)}$ and examined with light microscope. Ultrathin sections were cut and stained with uranyl acetate and lead citrate. The sections were examined with a JEOL 1010 transmission electron microscope at Faculty of Agriculture, Cairo University, Egypt

\section{Statistical analysis}

Statistical analysis was performed by using the SPSS statistic 14.0.Significant differences between groups were estimated by using the One-Way Analysis of Variance followed by Duncan`s Multiple Range Test.

\section{RESULTS}

Table 1 showed clearly that water collected from both Qarun and Burullus Lakes were contaminated with high levels of $\mathrm{Pb}$ and $\mathrm{Cd}$. The concentration of $\mathrm{Pb}$ and $\mathrm{Cd}$ in Lake Qarun were 0.074 and $0.006 \mathrm{ppm}$ respectively being much lower than that of Burullus Lake 0.112 and 0.011 respectively.

Table 1: concentrations of $\mathrm{Pb}$ and $\mathrm{Cd}(\mathrm{ppm})$ in water samples collected from Qarun and Burullus Lakes

\begin{tabular}{|l|l|l|}
\hline Parameters & Qarun Lake & $\begin{array}{l}\text { Burullus } \\
\text { Lake }\end{array}$ \\
\hline Lead (ppm) & 0.074 & 0.112 \\
\hline Cadmium (ppm) & 0.006 & 0.011 \\
\hline
\end{tabular}

The liver function analysis showed that there were no significant differences between levels of GGT in $M$. cephalus livers collected from both Lakes. ALT and AST were significantly increased in livers of fishes collected from Burullus Lake than Qarun Lake (Fig.1). 


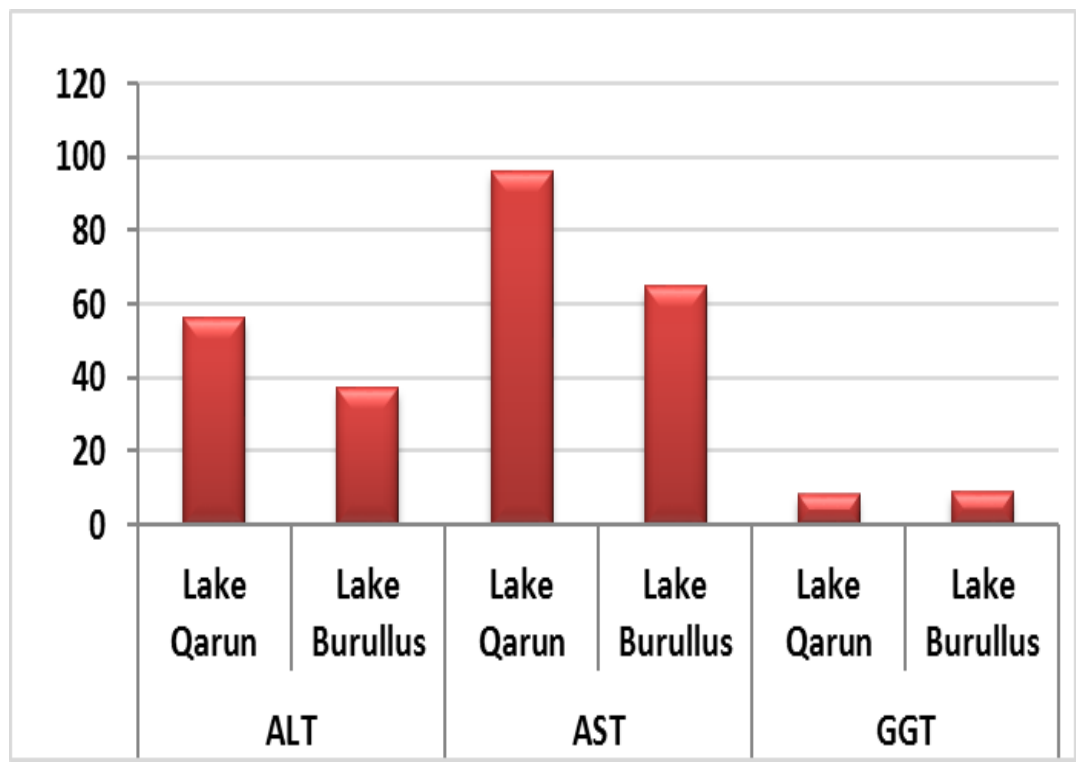

Fig.1.Liver enzymes of M. cephalus collected from both Qarun and Burullus Lake M. cephalus collected from Lake Burullus showed insignificant change in both urea and creatinine levels than those of Qarun Lake (Fig.2).

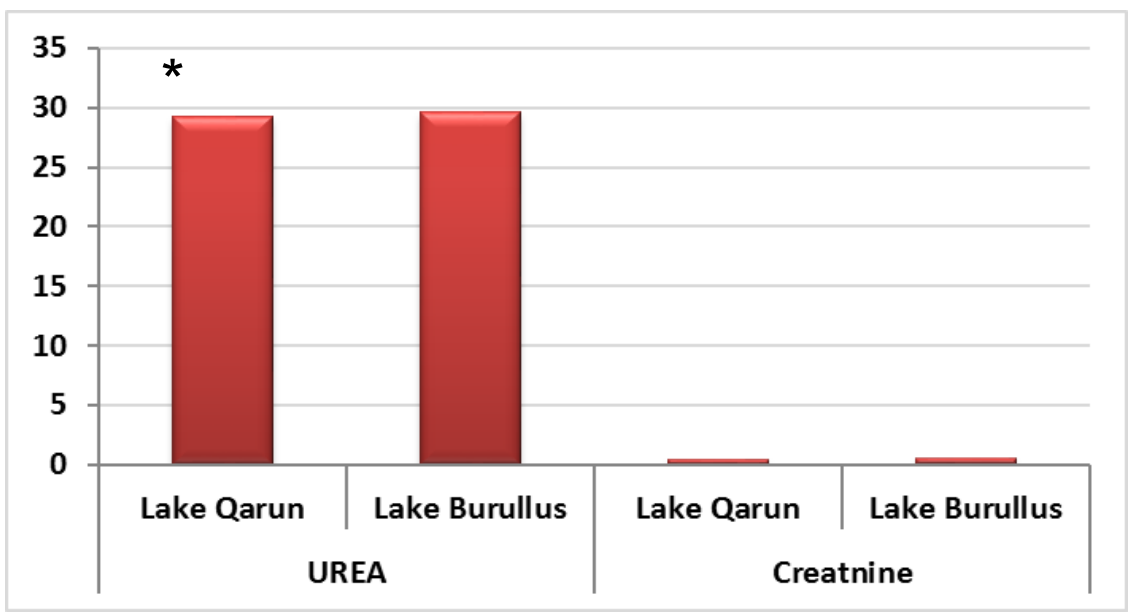

Fig.2.Kidney functions of M. cephalus caught from Qarun and Burullus Lakes

Cholesterol, Triglycerides, RF1,RF2, high density lipoproteins (HDL), low density lipoproteins (LDL), and very low density lipoproteins ( VLDL ) in the muscles of M.cephalus collected from Burllues Lake were highly significant increased while, total proteins were significantly decreased $(3.90 \mathrm{~g} / \mathrm{dl})$ in comparison with M.cephalus of Qaron Lake(2.7 g/dl)( Fig.3). 


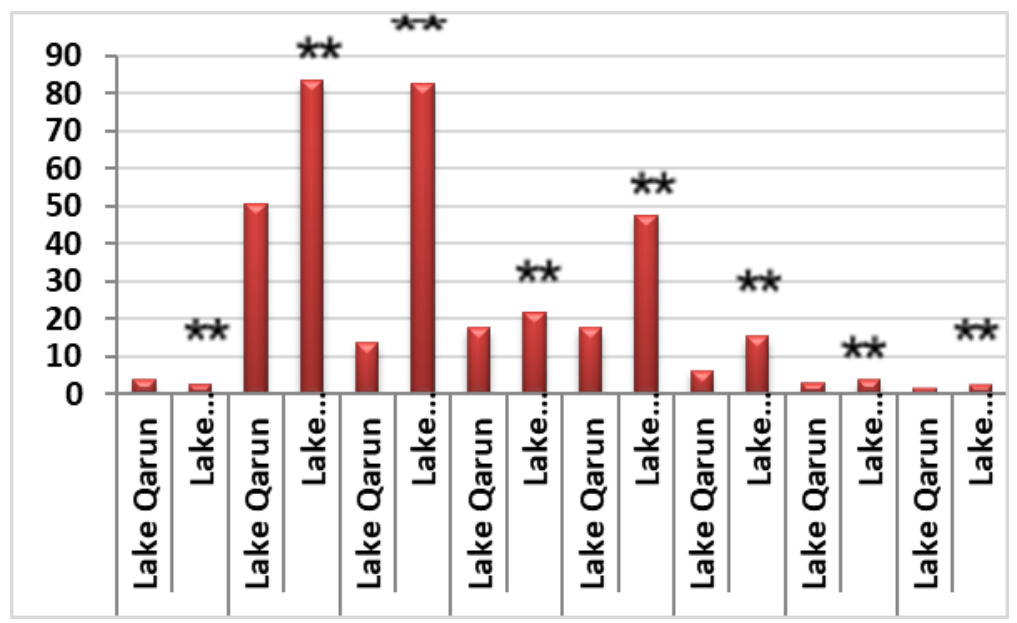

Fig.3. Biochemical analysis of M. cephalus tissues caught from Qarun and Burullus Lakes

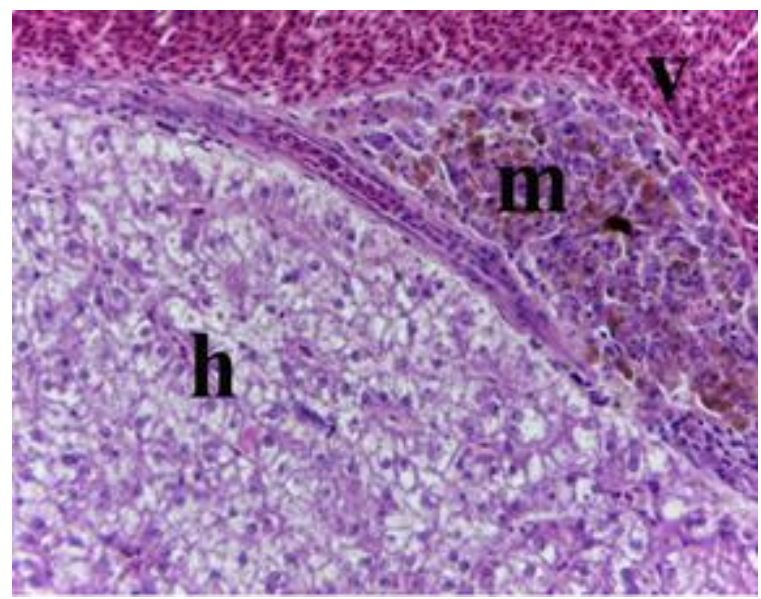

Fig. 4. Photomicrograph of a transverse section of the liver of $M$. cephalus collected from Burullus Lake showing congestion in the central vein $(\mathrm{V})$, vacuolated hepatocytes $(\mathrm{h})$ and hemosiderin granules $(\mathrm{m})$. (H\&E X400).

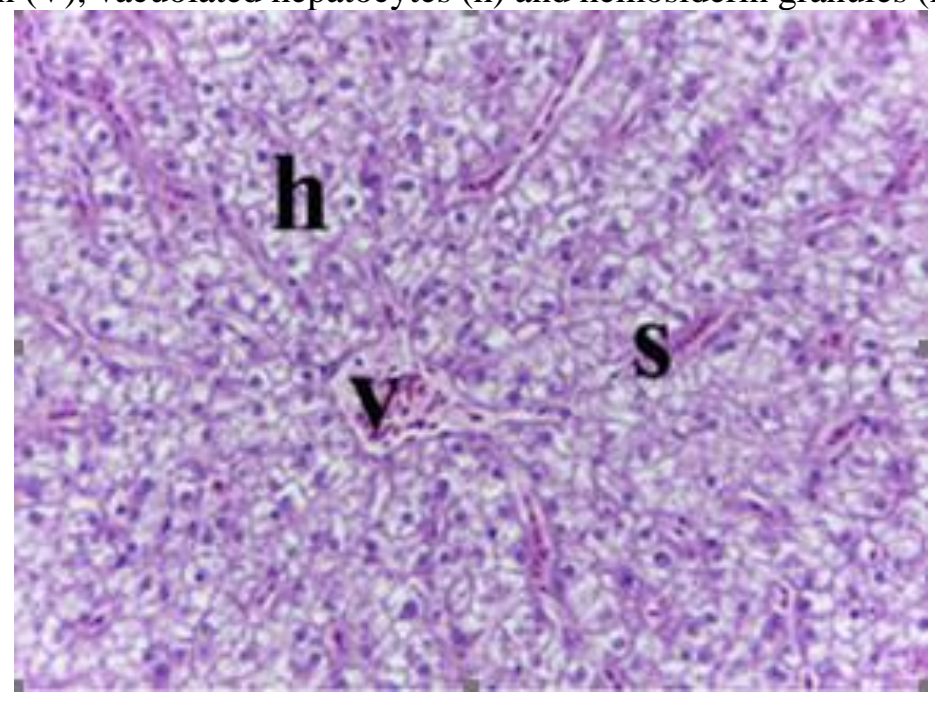




\section{Eman Helal et al.}

Fig. 5: Photomicrograph of a transverse section of the liver of $M$. cephalus collected from Burullus Lake showing congestion and hemorrhage in the vasodilated central vein $(V)$ and sinusoids (s) and vacuolated hepatocytes $(\mathrm{h})(\mathrm{H} \& \mathrm{E}$ $\mathrm{X} 400)$.

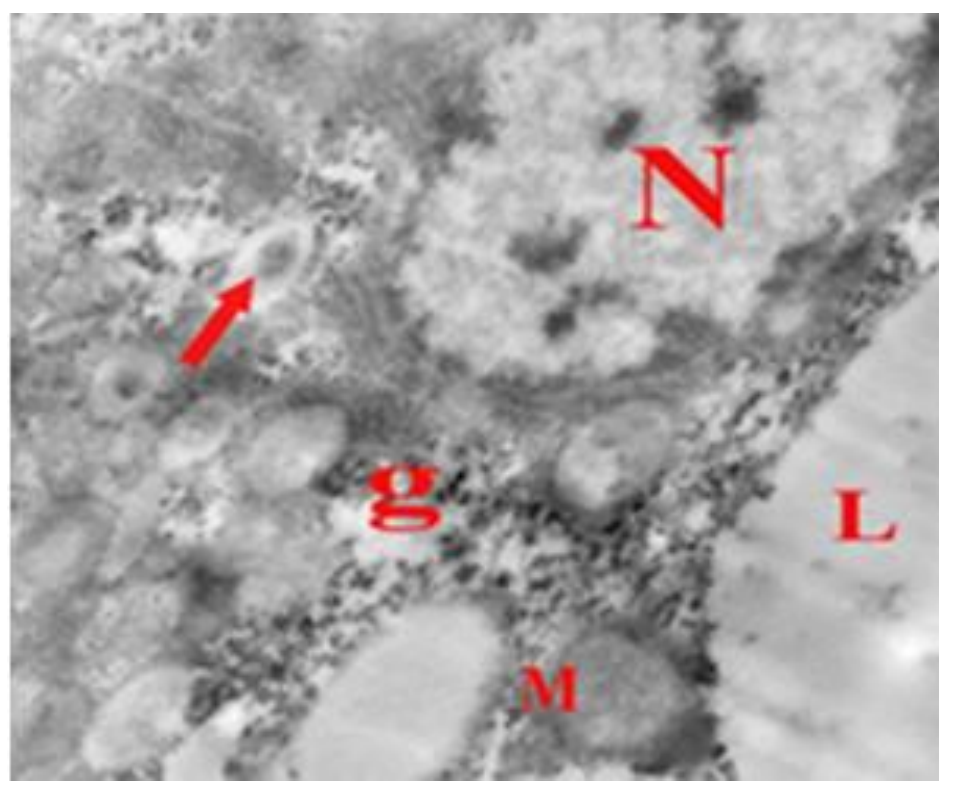

Fig. 6: Electron micrograph of the liver tissue of $M$. cephalus collected from Burullus Lake showing nucleus (N) which contains disintegrated chromatin and degenerated swelling mitochondria (M), lipid droplets (L), glycogen flakes and granules (g) and lysosomes (arrow). (Uranyl acetate and lead citrate X15000).

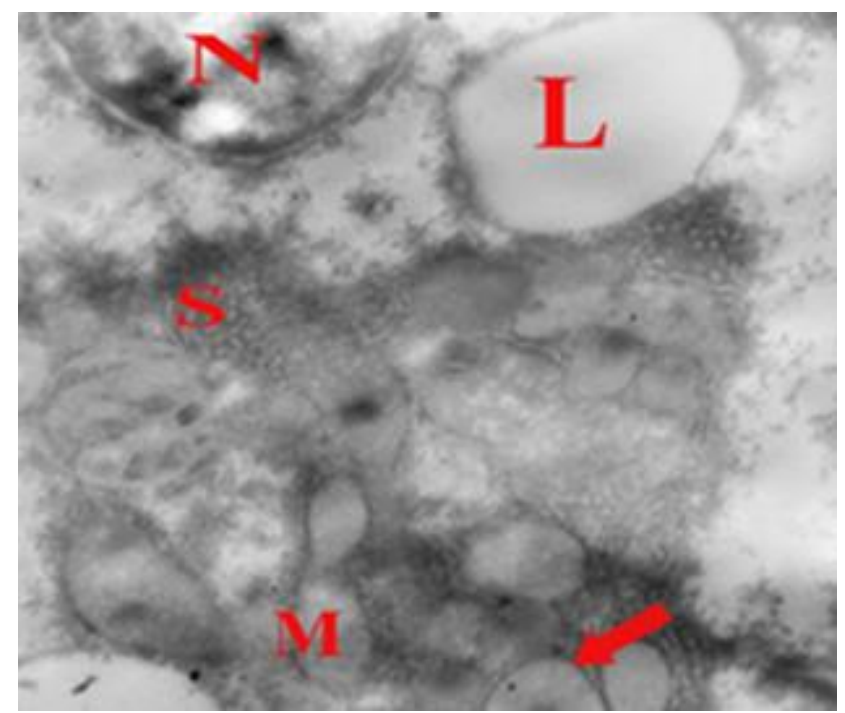

Fig. 7: Electron micrograph of the liver of $M$. cephalus collected from Burullus Lake showing double nuclear membrane around the nucleus (N) swelled and degenerated cylindrical mitochondria (M), large lipid droplets (L), smooth endoplasmic reticulum (S) and lysosomes (arrow) (Uranyl acetate and lead citrate X15000). 


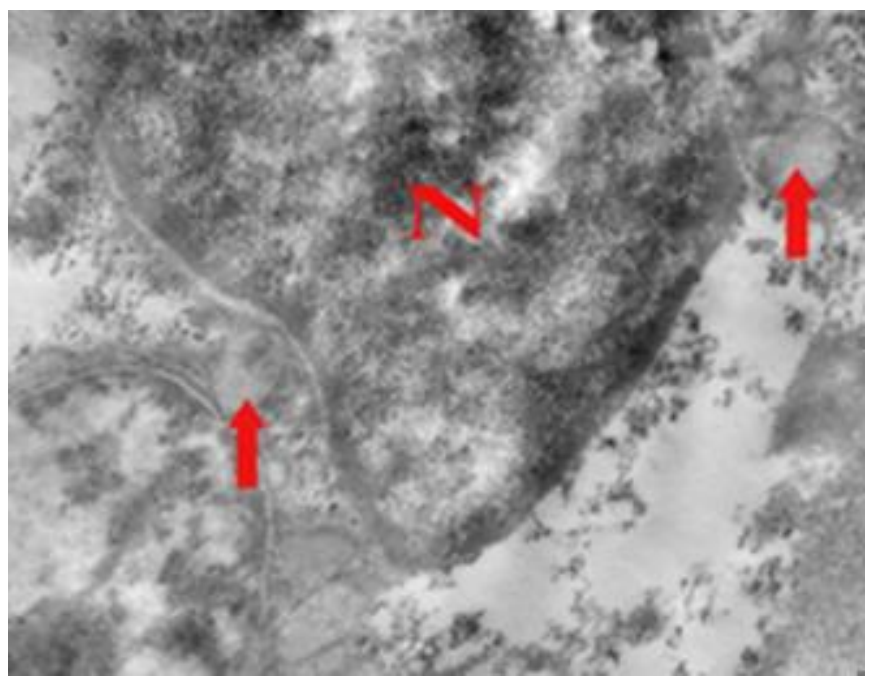

Fig. 8: Electron micrograph of the liver of M. cephalus collected from Burullus Lake showing corrugated nuclear wall of von Kupffer cell (N) and lysosomes (arrows) with debris of degenerated cytoplasmic organoids (Uranyl acetate and lead citrate X15000).

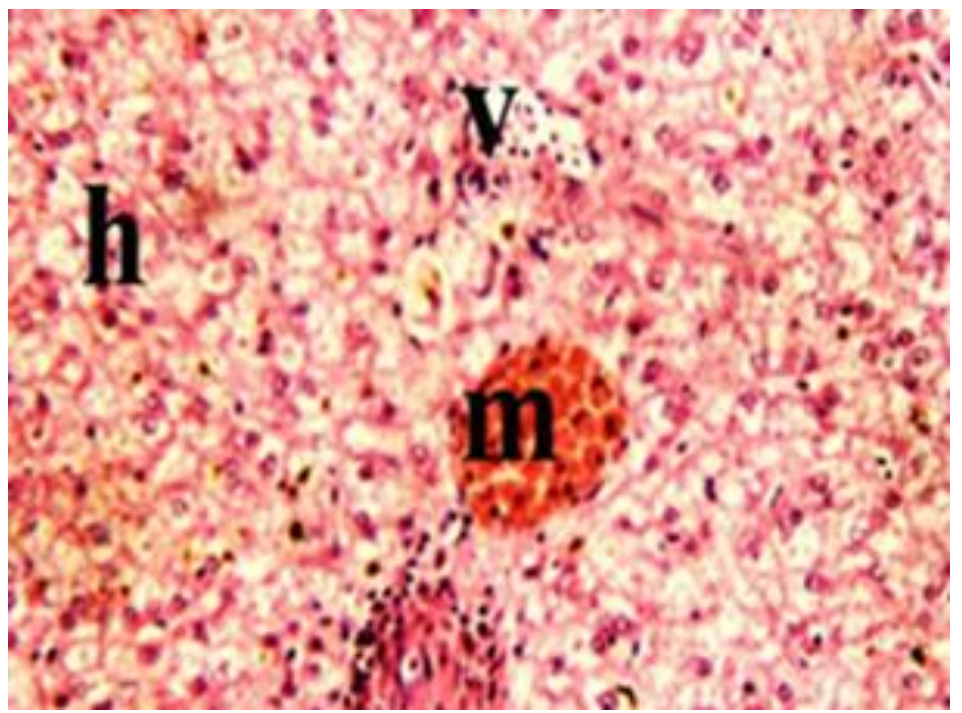

Fig. 9: Photomicrograph of a transverse section of the liver of $M$. cephalus collected from Qarun Lake showing vacuolated hepatocytes (h) with degenerated cytoplasmic organoids, aggregate of blood cells (v) and congested central vein $(\mathrm{m})$. (H\&E X 400) 


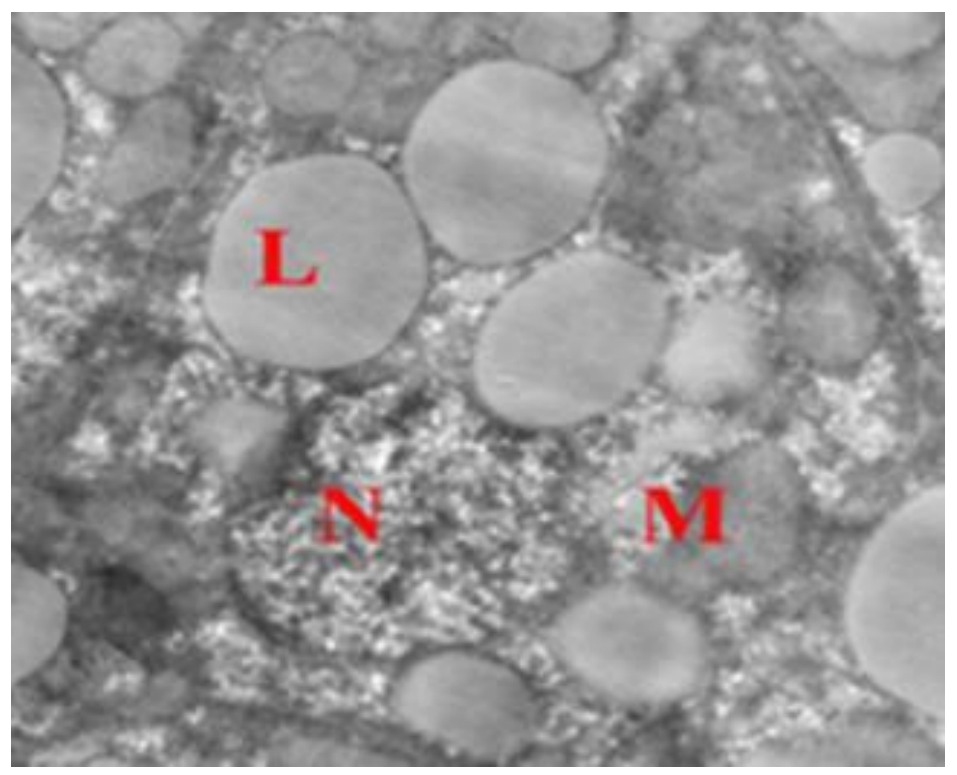

Fig. 10: Electron micrograph of the liver of M. cephalus collected from Qarun Lake showing apoptotic nucleus (N) and degenerated swelling cylindrical mitochondria (M), lots of lipid droplets (L) (Uranyl acetate and lead citrate X8000).

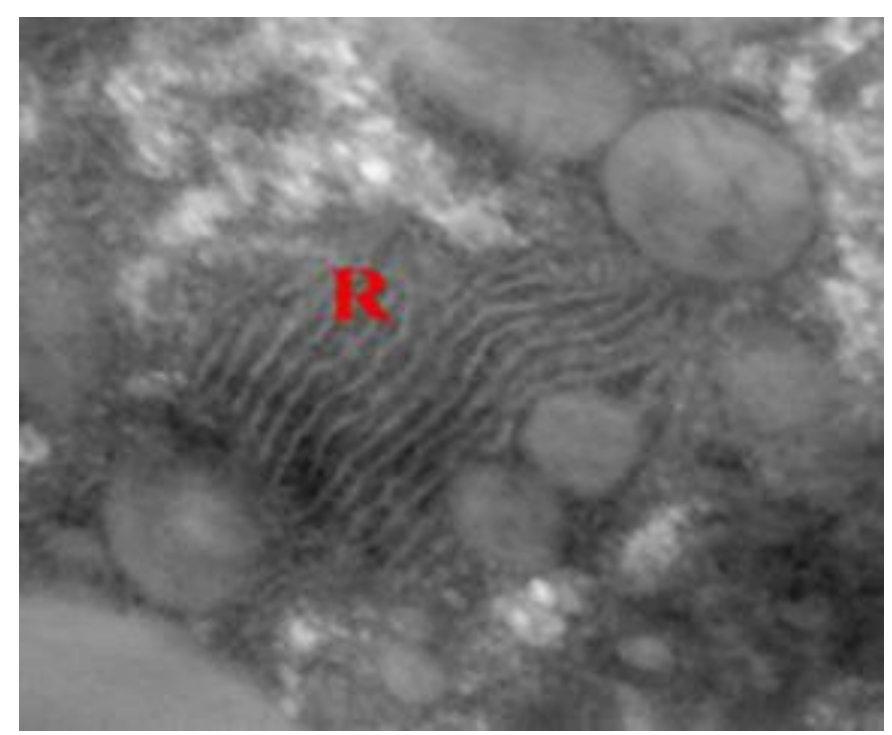

Fig. 11: Electron micrograph of the liver of M. cephalus collected from Qarun Lake showing dilated rough endoplasmic reticulum $(\mathrm{R})$ which is surrounded by debris of degenerated cytoplasmic organoids (Uranyl acetate and lead citrate X20000). 
Monitor of Water Quality Using The Grey Mullet...

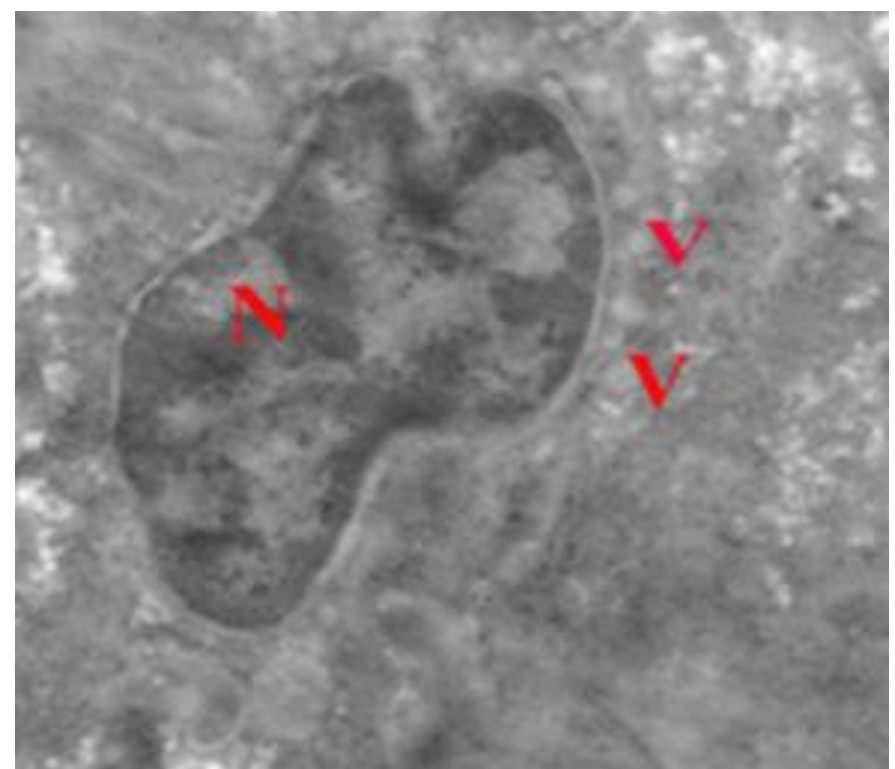

Fig. 12: Electron micrograph of the liver of M. cephalus collected from Qarun Lake showing corrugated wall of von Kupffer cell (N) and numerous vacuoles (V). (Uranyl acetate and lead citrate X15000).

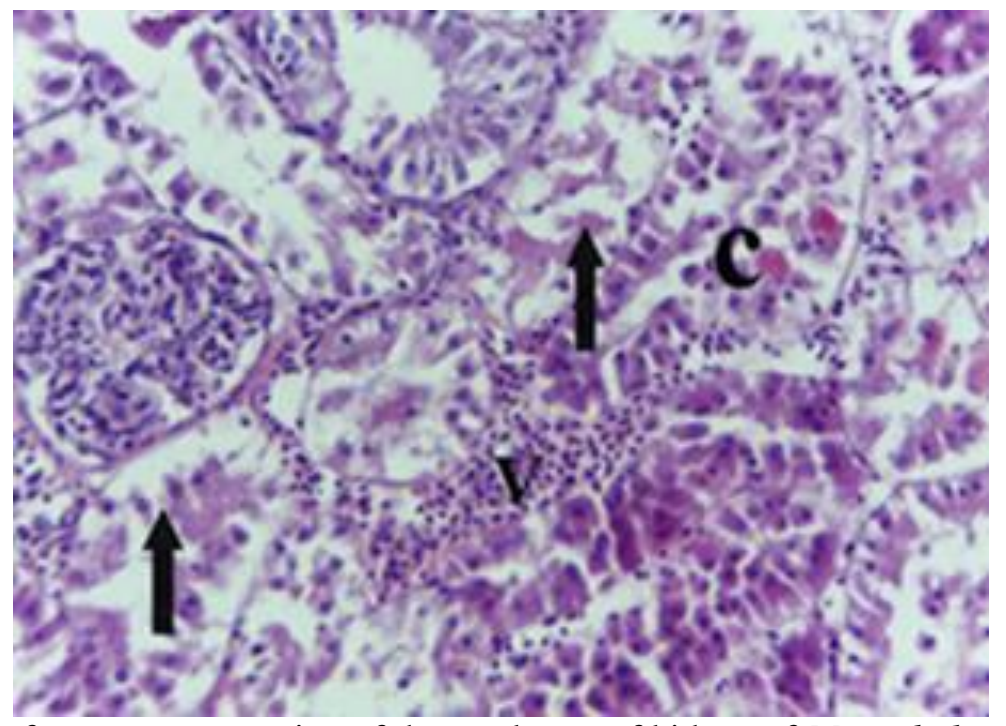

Fig. 13: Photomicrograph of a transverse section of the trunk part of kidney of $M$. cephalus collected from Burullus Lake showing desquamation in the epithelial lining of the proximal tubule (arrow), congestion in the blood vessels (V) and accumulation of Hyaline casts (C) (H\&E X400). 


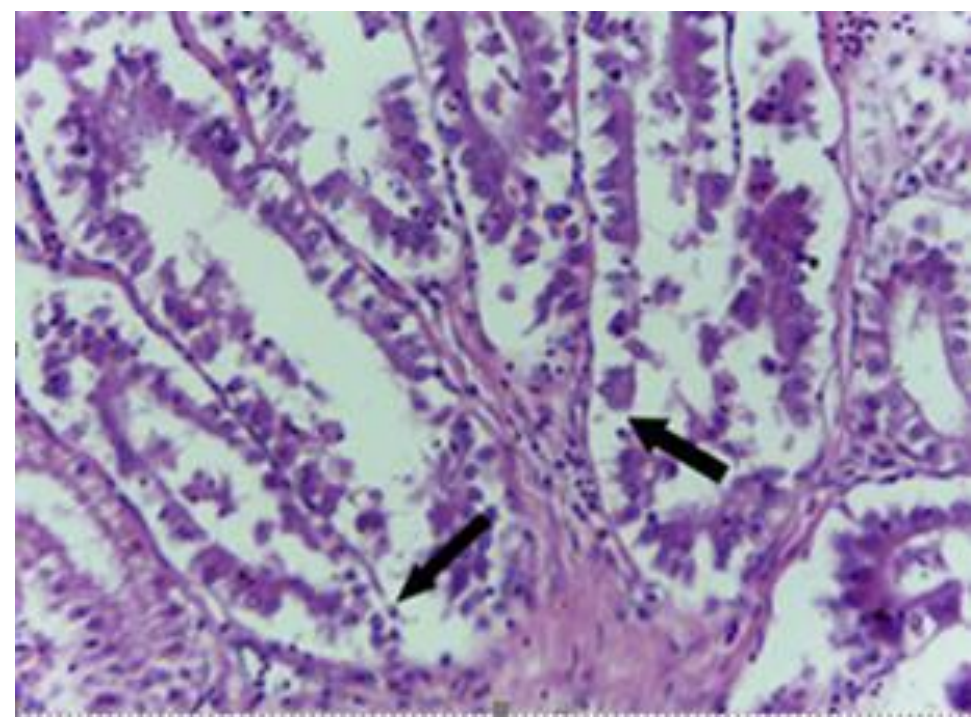

Fig. 14: Photomicrograph of a transverse section of the trunk kidney of M. cephalus collected from Burullus Lake, showing desquamation in the epithelial lining of the collecting tubule (arrow). (H\&E X400).

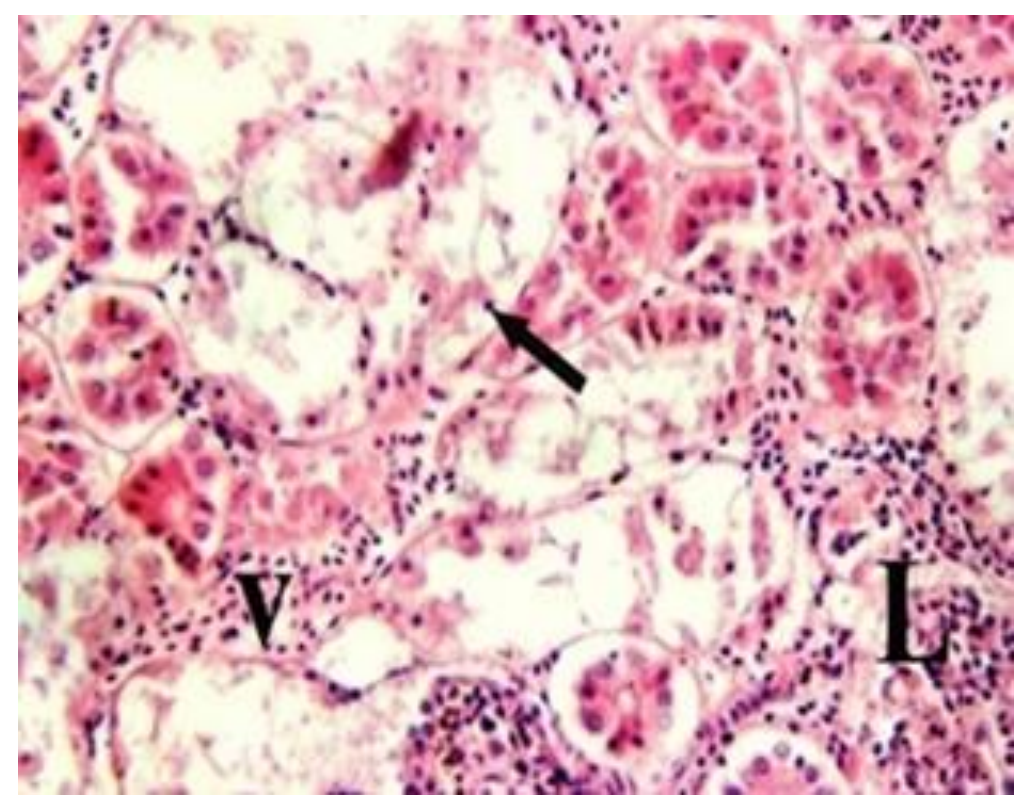

Fig. 15: Photomicrograph of a transverse section of the trunk part of the kidney of $M$.cephalus collected from Qarun Lake showing markedly desquamation of necrotic tubular epithelial lining (arrow), congestion in the blood vessels (V) and interstitial inflammatory infiltrate (L) (H\&E X 400).

\section{DISCUSSION}

Water is essential for existence of all living organisms and water resources are increasingly threatened by human populations, domestic sewages, agricultural uses, mining and industrial effluents may lead to deterioration in water quality and this deterioration may have negative impacts on aquatic ecosystem ${ }^{(\mathbf{1 2})}$. Lake ecosystems are vulnerable to heavy metal pollution. Among aquatic pollutants, heavy metals are considered as critical contaminants due to their strong impact on the stability of aquatic bodies, bioaccumulation in living organisms, toxicity and tendency to accumulate in water ${ }^{(\mathbf{1 3})}$.

The present study showed clearly that water collected from both Qarun and Burullus Lakes were contaminated with high levels of $\mathrm{Pb}$ and $\mathrm{Cd}$ and their concentrations in Lake Burullus were much higher than that of Qarun Lake. Lake Qarun has elevated concentrations of phosphorous and nitrogen that are conducive to algal blooms which affect the fish and animal life in the lake with the great dangerous impact on the human health ${ }^{(14)}$. 
The present findings are matching with results reported by EL-Kafrawy ${ }^{(15)}$ for Lake Burullus. Field study in Lake Burullus showed that the diversity of fishes was decreased from 32 to 25 species as a direct effect of pollution (16). In order to monitor pollutants, test organisms are needed in which these compounds can be traced at the tissue level as fish, aquatic invertebrates, aquatic plants and algae were used for this purpose (17). Analysis of liver functions in this study showed a highly significant increase in levels of ALT and AST in M. cephalus liver collected from Burullus Lake than those from Qarun Lake. Such elevation in liver enzymes may reflect the early toxic effects of heavy metals and other pollutants on the hepatic enzymes activities. Heavy metals caused an increase in ALT and AST activities and in levels of albumin, transferrin, cortisol, glucose and total proteins ${ }^{(18)}$.

Levels of cholesterol, triglycerides, high density lipoproteins (HDL), low density lipoproteins (LDL), very low density lipoproteins( VLDL ),RF1 and RF2 in the muscle of mullet collected from Burullus Lake were significantly increased in comparison with mullet of Qarun Lake, while total proteins were significantly decreased and this may be due to defensive mechnisms in the fish to overcome the degenerative effects of heavy metals toxicity present in the two lakes. This reduction of tissues total proteins could be attributed to several pathological changes including plasma dissolution, renal damage and decreased liver protein synthesis ${ }^{(19)}$.Histopathological investigations in this study revealed that liver of mullet collected from both Lakes were suffered from marked area of hemorrhage, aggregates of hemosiderin granules and vacuolated hepatocytes. Sections of the kidney showed markedly necrotic tubular epithelial lining with scattered apoptotic cells and interstitial inflammatory infiltrate. The impact of water pollution on histopathological characters of Oreochromis niloticus was studied and sections of liver revealed congestion and hemorrhage in the hepatic sinusoids; hepatic cells were suffered from vacuolar degeneration, while the kidneys showed sever degenerative changes of the renal tubular cells and coagulative necrosis ${ }^{(\mathbf{2 0})}$.

The fish liver is considered an interesting model for studying the interaction between environmental factors and health of the fish as it reflects the status of aquatic ecosystem $^{(25)}$. Fish liver is considered as a key organ that controls various life functions such as metabolism of protein, lipid and carbohydrates, bile formation, glycogenolysis and detoxification. In addition, it acts as a center for storage of many substances, mainly glycogen and lipids ${ }^{(26)}$. Liver is one of the most affected organs by contamination in water due to its position, function and blood supply (27). Depleted glycogen and lipid resulted in vacuolation in hepatocytes of freshwater fish after pesticides poisoning ${ }^{(28)}$.The hepatic vasodilation probably is acting as a device for greater transport of pesticides and this suggests that liver helps in detoxification $^{(29)}$.

In this study ultrastructural observation revealed increased degenerated, swelled and cylindrical mitochondria, accumulation of large lipid droplets, increased lysosomes and debris of cytoplasmic organoids was detected. While, hepatocytes from Qarun Lake showed apoptotic nuclei and degenerated, swelled and cylindrical mitochondria, increased lipid droplets with dilated rough endoplasmic reticulum. Presence of large lipid droplets in liver was related to heavy metal contaminants ${ }^{(30)}$.

The degree of damage in the liver cells was indicated by swollen mitochondria with electron transparent matrix and by dilatation and vacuolation of the endoplasmic reticulum system ${ }^{(31)}$. The pathological changes observed in the present study such as necrosis of renal tubules and desquamated epithelial cells and hemorrhage suggested that pesticides enter the kidney and distrupt their normal functioning. Necrosis observed in the renal tubules affected the metabolic activities and promote metabolic abnormalities in fish (32). Lymphocytic infiltration in the kidney is explained as a defense mechanism in the fish to counter the toxic metabolites. The present results indicated that the biochemical parameters and histopathological investigations.

\section{REFERENCES}

1- El-Sherif S and Abd El-Ghafour S (2016): Investigation of the quality properties and nutritional values of four fish species from Lake Qaroun, Egypt. International Journal of Chem.Tech. Research, 9 (4) : 16-26.

2- El-Zeiny A and El-Kafrawy $H$ (2017): Assessment of water pollution induced by human activities in Burullus Lake using Landsat 8 operational land imager and GIS. The Egyptian Journal of Remote Sensing and Space Science, 20: 49-56.

3- Naouel, O Bourhane-Eddine B and Haroun C (2018): Modeling environment contamination with heavy metals in flathead grey mullet Mugil cephalus and upper sediments from North African coasts of the Mediterranean Sea. Science of Total Environment , 639: 156-174.

4- Eneji I S (2010): Spatial and temporal variation in the heavy metals loading of River Benue in Makurdi Metropolitan Area. Int. J. Environ. Res., 12(4): 4128-4140. 
5- Wang WX (2011): Incorporating exposure into aquatic toxicological studies: an imperative. Aquat. Toxicol., 105:9-15.

6- Wael, A, Khalid H, Abdel-Khalek A and Abo-Hegab S(2012): Genotoxic effects of metal pollution in two fish species, Oreochromis niloticus and Mugil cephalus, from highly degraded aquatic habitats. Fundamental and Molecular Mechanisms of Mutagenesis, 746(1):7-14.

7- Skoczyńska A, Poreba R, Sieradzki A, Andrzejak R and Sieradzka U (2002): The impact of lead and cadmium on the immune system. J. National Institute of Health, 53(3): 259-264.

8- Deborah E, Keil J, Berger-Ritchie, Gwendolyn A and Millin M (2011): Testing for toxic elements: a focus on arsenic, cadmium, lead and mercury. Laboratory Medicine, 42:735-742.

9- Nathan W, Peter R, Teasdale $R$ and Connolly M (2013): Use of flathead mullet (Mugil cephalus) in coastal biomonitor studies. Marine Pollution Bulletin, 69(1-2):195205

10- Minckley WL (1973): Fishes of Arizona. Phoenix Arizona .pp: 257-258.

11- Wael A, Khalid H, Abdel-Khalek A and Abo-Hegab $S$ (2012): Genotoxic effects of metal pollution in two fish species, Oreochromis niloticus and Mugil cephalus, from highly degraded aquatic habitats. Fundamental and Molecular Mechanisms of Mutagenesis, 746(1):7-14.

12-Bancroft JD and Gamble M (2008): Theory and Practice of Histological Techniques. $6^{\text {th }}$ ed. Churchill Livingston Edinburgh, London and New York.

13-Karnovsky A (1965): formaldehyde glutaraldehyd fixative of high osmolarity foruse in electron microscopy. J. Cell Biol., 27:137-139.

14-Mollenhauer H (1964): Plastic embedding mixture for use in electron microscopy. Stain Technol., 39: 111-114.

15-Richardson, KC Jarett $L$ and Finke $E$ M (1960): Embedding in epoxy resins for ultrathin sectioning in electron microscopy. Stain. Technol., 35: 313-323.

16- Gad A, Ali R and El-Zeiny A (2011): Negative impacts of man-made activities on water quality, Egypt. Conference of integrated water resources management in the Mediterranean at Agadir, Morocco. Researchgate, 1-19.

17- Has-Schon E, Bogut I and Strelec I (2006): Heavy metal profile in five fish species included in human diet, domiciled in the end flow of River Neretva (Croatia). Arch. Environ. Contam. Toxicol., 50(4): 545-551.

18- Hussein H, Amer, $\mathbf{R}$ Gaballah A, Refaat $\mathbf{Y}$ and AbdelWahab A (2008): Pollution monitoring for Lake Qarun. Advances in Environmental Biology, 2 (2):70-80.

19- El-Kafrawy S, Khalafallah A, Omar M, Khalil M, Yehia A and Allam M (2015): An integrated field and remote sensing approach for water quality mapping of Lake Burullus, Egypt. Int. J. Environ. Sci. Eng., 6: 15-20.

20- El-Adawy A, Negm A, Elzeir M, El-Shinnawy I and Nadaoka K (2013): Modeling the hydrodynamics and salinity of El-Burullus Lake (Nile Delta, Northern Egypt). J. Clean Energy Technol., 1 (2):65-72.

21- El-Sheekh M (2009): River Nile pollutants and their effect on life forms and water quality. Monographiae Biologicae, 89: 395-405.

22- Özgür F and Ferit K (2010): Individual and combined effects of heavy metals on serum biochemistry of Nile tilapia, Oreochromis niloticus. Archives of Environmental Contamination and Toxicology, 58(1): 151-157.

23- Salah EL-Deen M, Salah R, Issa A and AboHegab S(2000): Some metallic alterations in grass carp,Ctenopharyngo donidella ,by exposure to mercury and zinc .Egypt.J.Aquat.Biol. Fish, 4(3):21-43.

24- Osman M, EL-Fiky S, Soheir Y and Abeer A (2009): Impact of water pollution on histopathological and electrophoretic characters of Oreochromis niloticus fish. Research Journal of Environmental Toxicology, 3: 9-23.

25-Hinton DE, Lantz RC, Hampton JA, Mc Cuskey PR and Mc Cuskey RS (1987): Normal versus abnormal structure: considerations in morphological responses of teleosts to pollutants. Environ. Health Persp., 71:139-146

26-El Bakary N and El-Gammal H L (2010): Comparative histological, histochemical and ultrastructural studies on the liver of flathead grey mullet (Mugil cephalus) and sea bream (Sparus aurata) Global Veterinaria, 4(6):548-553 .

27-Camargo M and Martinez C B (2007): Histopathology of gills, kidney and liver of a neotropical fish caged in an urban stream. Neotrop. Ichthyol., 5: 327-336.

28-Agarwal S J and Srivastava A K (1980): Hematological response in a freshwater fish to experimental manganese poisoning. Toxicol ., 17: 97- 100.

29-Sharma K and Sharma J (2016): Histopathological alterations in the liver and kidney of fish Labeo Rohita after exposure of endosulfan and lindane.International Journal of Advances in Science Engineering and Technology, 4(3):237-240.

30-Vasanthi L A, Revathi P, Mini J, Munuswamy N (2013): Integrated use of histological and ultrastructural biomarkers in Mugil cephalus for assessing heavy metal pollution in Ennore estuary, Chennai. Chemosphere,91 (8):1156-1164.

31 -Rojik I, Nemcsók J and Boross L (1983): Morphological and biochemical studies on liver, kidney and gill of fishes affected by pesticides. Acta Biol. Hung., 34(1):81-92

32-Yokote M (1982): Digestive system. In: An Atlas of Fish Histology-Normal and Pathological Features.T. Hibiya ed. Kodansha Limited, Tokyo, pp: 74-93. 